POSITIVE PRESSURE COLUMNS USED FOR SOLVENT

CLEANUP OR CHROMATOGRAPHY

by

Department of Chemistry

University of Georgia

Athens, Georgia 30602

This report was prepared as an account of work sponsored by the United States Government. Neither the United States nor the United States Energy Research and Development Administration, nor any of
their employees, nor any of their contractors, subcontractors, or their employees, makes any warranty, express or implied, or assumes any legal or usefulness of any information, apparatus, product or process disclosed, or represents that its use would not infringe privately owned rights.

July 1977

PREPARED FOR THE

U. S. ENERGY RESEARCH AND DEVELOPMENT ADMINISTRATION UNDER CONTRACT E(38-1)854 


\section{DISCLAIMER}

This report was prepared as an account of work sponsored by an agency of the United States Government. Neither the United States Government nor any agency Thereof, nor any of their employees, makes any warranty, express or implied, or assumes any legal liability or responsibility for the accuracy, completeness, or usefulness of any information, apparatus, product, or process disclosed, or represents that its use would not infringe privately owned rights. Reference herein to any specific commercial product, process, or service by trade name, trademark, manufacturer, or otherwise does not necessarily constitute or imply its endorsement, recommendation, or favoring by the United States Government or any agency thereof. The views and opinions of authors expressed herein do not necessarily state or reflect those of the United States Government or any agency thereof. 


\section{DISCLAIMER}

Portions of this document may be illegible in electronic image products. Images are produced from the best available original document. 


\title{
POSITIVE PRESSURE COLUMNS USED FOR SOLVENT CLEANUP OR CHROMATOGRAPHY
}

B. P. Semonian, J. A. Lubkowitz', and L. B. Rogers ${ }^{2}$

\begin{abstract}
By utilizing a mercury pressure valve, a volatile solvent, n-pentane, was conveniently used in a classical gravity-feed liquid chromatographic column. The pseudo-closed system maintained column efficiency by prevenling the formation of column bubbles. The system was efficient in reducing solvent evaporation as well as preventing water condensation at the column outlet. Since free solvent vapors were eliminated, the system provided an additional safety factor when a flammable solvent, such as n-pentane, was employed. While the columns were used for solvent cleanup, a small modification would transform the system into a solute purification apparatus.
\end{abstract}

'On leave from Instituto Venezolano de Investigaciones Cientificas, Apartado 1827, Caracas (Venezuela).

${ }^{2}$ To whom all correspondence should be directed.

"This report was prepared as an account of work sponsored by the United States Government. Neither the United States nor the United States Energy Research and Development Administration, nor any of their employees, nor any of their contractors, subcontractors, or their employees, makes any warranty, express or implied, or assumes any legal liability or responsibility for the accuracy, completeness or usefulness of any information, apparatus, product or process disclosed, or represents that its use would not infringe privately-owned rights." 


\section{INTRODUCTION}

There are still many applications, such as solvent and sample purifications, which still utilize the classical gravity-feed columns. However, the use of volatile solvents often generates problems in those (gravity-feed) systems. The most common inconveniences are, first, the formation of gas bubbles in the column bed, which renders the column useless and, second, the loss of mobile phase by evaporation from the solvent reservoir. In addition, the dissolution of water vapor (from the air) at the column outlet, can contaminate the sample or solvent.

The columns were based on the principle of an addition funnel (1), and with the aid of a simple mercury pressure valve, the problem of gas bubble formation was eliminated when purifying $\underline{n}$-pentane over silica gel. The loss of $\underline{n}$-pentane through evaporation was substantially reduced and water contamination was essentially eliminated. The pseudo sealed system utilized the partial pressure of the $\underline{n}$-pentane to generate a pressure of approximately 50 torr greater than the ambient pressure.

The pressure served several functions. It served to collapse any bubbles already present in the column. At the same time, the positive pressure also kept air from leaking around the sides of the stopcock which often generates additional bubbles in the column packing through evaporation. Since the system was a pseudo closed one, the liquid vaporized to the point of establishing its characteristic partial pressure. After this pressure had been achieved, further losses due to evaporation were eliminated. This system could also be used to exclude atmospheric gases by employing a purge gas.

\section{EXPERIMENTAL}

\section{Apparatus}

A diagram of the system is shown in Figure 1. All unions used were 24/40 ground glass unions. The column was $60 \mathrm{~cm} \times 2.54 \mathrm{~cm}(0 . d$.) and $2.24 \mathrm{~cm}$ (i.d.). The 
sintered-glass frit was of medium porosity. The top joint of the reservoir was fitted with a tubing-adapter. A latex rubber tube, was used to connect the reservoir tubing adapter, through a glass ' $T$ ', to' the venting arm that followed the column. The third port of the ' $T$ ' was connected by latex tubing to a $4 \mathrm{~mm} 0 . d$. glass tube which had been inserted through a two-hole rubber stopper and into the mercury reservoir. (An optional blast tank could be placed as a branch at any convenient location along the latex tubing.) The pressure was regulated by the mercury reservoir, and it was adjusted by raising or lowering the height of the glass tube in the mercury pool. Once the pressure had been set to a desired value, no other adjustments were necessary.

\section{Procedure}

The silica gel was first dried overnight at $170^{\circ} \mathrm{C}$. It was then slowly poured into the column which had previously been filled with n-pentane. The top reservoir was then attached and also filled with $\underline{n}$-pentane.

The routine operation of the column consisted of four steps: a) Filling the reservoir, b) cleaning the receiver of vapor by blowing filtered house air into it, c) clamping the receiver to the bottom of the column, and d) adjusting the flow rate of liquid to a desired level. Once those steps had been taken, the column required no further maintenance.

\section{RESULTS AND DISCUSSION}

We have repeatedly used this technique for cleaning up technical grade $\underline{n}$-pentane. The advantages of this system are, first, that slow flow rates can be used without vaporization losses of the $\underline{n}$-pentane becoming a problem. We have used up to 12 hours to pass 2 liters of $\underline{n}$-pentane without appreciable loss. Second, more efficient columns were maintained since bed-disrupting bubbles were prevented from forming. Third, 
safety was increased because an increase in ambient temperature could not generate either higher column pressures or noticeable amounts of gaseous n-pentane. (Nevertheless, this system was operated in a good fume hood!) Fourth, the pseudo-closed system eliminated the access of water vapor to the outlet of the column. Finally, accidental degradation of the column material by water adsorption was reduced. Even in cases where the column was accidently allowed to run dry and to remain in that condition for several hours, there was no evidence that atmospheric water had penetrated the system to an extent that deactivated or seriously impaired the operation of the column. Obviously, this type of technique could also be used to exclude atmospheric gases if an appropriate purge gas were employed.

The system was ideal for solvent clean up, and it can be readily adapted to fraction collection by incorporating several containers inside the receiver flask. In this mode of operation, one would (most probably) use the optional blast tank.

\section{ACKNOWLEDGEMENT}

This work was supported by the U. S. Energy Research and Development Administration through Contract No. E(38-1)-854 . 


\section{LITERATURE CITED}

1. "Separatory funnels, addition, pressure equalizing," Item no. 5237-H10, Arthur H. Thomas Co. Catalog, 1976. 


\section{FIGURE CAPTION}

'igure 1. Column with upper and lower (2 liter) reservoirs.

1 
